\title{
The Effectiveness of Corporal Punishment in Dealing with Deviant Behaviour in Pupils in Schools
}

\author{
*Wadesango N, \\ **Gudyanga $\mathrm{E}$, \\ ${ }^{* *}$ Mbengo $\mathrm{F}$ \\ ** University of Fort Hare, TLC, East London, RSA \\ *Midlands State University, Faculty of Education, Gweru, Zimbabwe \\ nwadesango@ufh.ac.za
}

\section{Doi:10.5901/mjss.2014.v5n9p378}

\section{Abstract}

The research set out to investigate and establish the effectiveness of corporal punishment in dealing with deviant behaviour in pupils in Chibuwe Cluster Schools in Chipinge District. The research was prompted by the recurrence of deviance in pupils even after numerous attempts to control and eradicate it with corporal punishment. Descriptive survey research design was used. Stratified random sampling was done to create a sample representative of the population. The sample comprised twentyfive pupils, fifteen form four pupils and ten grade seven pupils. There were also twenty-five teachers, fifteen secondary school teachers, ten primary school teachers as well as five school heads and five members of the school development committees which summed up to sixty respondents. Respondents were sampled from two rural primary and three rural secondary schools selected from eleven schools in the cluster. Data were collected through self administered questionnaires and face to face interviews. The study found out that there is very rare to no procedural and recommended corporal punishment in Chibuwe Cluster Schools. It was recommended that schools should widen and diversify their disciplinary strategies to include rewards, discussions, explanation and others.

Keywords: Corporal punishment; deviance, behaviour; discipline

\section{Introduction}

Deviant behaviour seems to be a cause for concern in various schools in Zimbabwe, both primary and secondary. Historically, deviance was always assumed to be caused by mischief on the part of the pupils involved and as such the same treatment for different types of misbehaviour was given. By then any deviant behaviour was sanctioned by solid punishment in form of corporal punishment or heavy manual work. Constitution of Zimbabwe (1979) as amended in 1990 by then allowed 'moderate' corporal punishment in 'appropriate circumstances' upon a person under the age of 18 years. This also applies to pupils in schools who are usually under 18 years of age. Such a clause in the national constitution is enough evidence that deviant behaviour in the juveniles is existent and needs to be controlled.

Ezewu (1996) states that deviant behaviours exhibited by pupils in schools emanate from different causes and for that reason different behaviours should be given different treatment, depending on their particular causes as well as the treatment's effectiveness. This brought the idea of having various strategies for dealing with deviant behaviours in pupils among them, corporal punishment, social therapy (counselling), assigning duties of responsibility to deviant pupils in class, withdrawal of favours from deviant pupils, rewarding good behaviour and many others. Despite having various strategies of combating deviant behaviour in schools, cases of deviant acts still exist. Some of the deviant behaviours exhibited by pupils, especially in some boarding schools threaten the existence of other junior pupils. The deviant behaviour by bullies adversely affects new pupils' stay at schools and academic achievements as they become afraid and live in fear which is not conducive to learning.

The widely used strategy of dealing with deviant behaviour, corporal punishment, was temporarily abolished soon after independence, in 1982. Three years later, corporal punishment was brought back. Zindi (1995) says that discipline had become a problem in schools and this breakdown of discipline and control of pupils forced the Ministry of Education and Culture to reintroduce corporal punishment in 1985 through the act of parliament. In 1989 the Supreme Court of Zimbabwe contested corporal punishment in schools and won its case that corporal punishment should be outlawed in 
schools. In 1990, the then Secretary for Education, Sports and Culture S.J. Chifunyise, in condemning corporal punishmentcompared it to a fight with the exception that in this case the pupil is not allowed to fight back and has to endure the agony, the pain and the deprivation of human dignity.

However in 1992 the Government of Zimbabwe nullified the 1989 Supreme Court ruling and reintroduced corporal punishment on boys' buttocks and girls' hands. Corporal punishment was legalised again. Secretary of Education Circular P. 35, 1993; Statutory Instrument 65 of the Constitution of Zimbabwe, 1992 reads, "In Zimbabwe, corporal punishment should be inflicted only by the school head, (who) can delegate (it) to any one of the senior teachers. If delegated, it must be carried out in the presence of the head and be inflicted on the buttocks with a suitable strap, cane or smooth light switch."

Shumba et al (2001); Shumba (2003); and Zindi(1995) noted that although the head is the only officer within the school with authority to use corporal punishment on pupils, it is now uncommon in Zimbabwe to find some school heads being charged for excessively canning pupils. This sort of an impunity leaves the corporal punishment strategy prone to abuse by school heads. They claim that emotions in disciplining the offensive pupils can overwhelm the school heads and they end up hurting the pupils. The effectiveness of any abused strategy is greatly questionable.

\subsection{Corporal punishment}

According to Straus and Stewart (1999:58), "Corporal punishment refers to the use of force to cause pain but not injury, for the purposes of correction or control." The Texas Education Code contends that corporal punishment is the deliberate infliction of physical pain by hitting, paddling, spanking, slapping or any other physical means used as a means of discipline. Other authorities; Cashmore and deHaas (1995) also define corporal punishment as the use of physical force towards a child for the purposes of control and / or correction and as a disciplinary penalty inflicted on the body with the intention of causing some degree of pain and discomfort, however mild. The last but not least, Shumba (2003:145) says, "Corporal punishment refers to intentional application of physical pain as a method of changing behaviour."

Among the definitions from the above scholars, words and phrases such as "deliberate or intentional, correction and control, pain, injury and mild' commonly feature. These are the key terms that define corporal or physical punishment that is in this study. It can be noted that the authorities above converge on the following facts: Corporal punishment involves the deliberate and intentional use of physical force towards a child. The physical force is applied knowingly and with intent. The force is intended to cause physical pain (Straus and Stewart 1999; Cashmore and deHaas, 1995; Shumba, 2003). Causing injury is not the intention for using corporal punishment and that is why Cashmore and deHaas (1995) say that the degree of pain and discomfort caused by corporal punishment should be mild. The pain caused by corporal punishment is for behaviour correction and control.

In all the five definitions of corporal punishment, there is a unanimous agreement that the purpose of corporal punishment is to control or correct pupils' behaviour so that they become disciplined. They view corporal punishment as one of the techniques that is used to achieve discipline with Shumba (2003) clearly stating that corporal punishment is used as a method of changing behaviour. Researches have shown that even the very pupils to whom corporal punishment is administered, the majority of them are of the feeling that teachers and school heads use corporal punishment to control pupils who are wrongdoers. The results of a study carried out in five rural secondary schools in Masvingo by Prof. Shumba's research revealed that out of the 200 pupils questioned on why teachers use corporal punishment in schools, 169 respondents (84.5\%) believed that it is because they want to control pupils who do wrong things.

Socialisation of children in an environment where corporal punishment is cherished and commonly used might also have contributed to pupils embracing corporal punishment as an acceptable technique that has the ability to control their behaviour. Some parents who grew up being beaten at home or school claim that they never suffered any negative consequences. They cherish the beatings they received when they were young and attribute their educational success to corporal punishment (Poole et al. 2003).

\section{Research Methodology}

Cohen and Manion (1994) assert that a research design is a plan, structure and strategy of investigation to obtain answers to research questions. In this research the cross-sectional descriptive survey research design was used. This survey was selected because of its appropriateness to source views on issues to be examined. Chiromo (2006) post that descriptive surveys are primary concerned with finding out. Its strength is on investigating the present status of phenomena being studied. In this case the author sourced views on the effectiveness of corporal punishment in schools 
as it is used in combating deviance behaviour in pupils. The population targeted by this research included primary and secondary school teachers and school heads, grade seven and form four pupils and community parents. There areabout two hundred and forty-two (242) grade seven and form four pupils, slightly above one hundred and twenty (120) teachers and five (5) school heads in the five schools from where the sample was drawn out. The community parents population is represented by school development committee members in the sample. Best and Kaan (2003) define a sample as a small proportion of a population selected for the study. The stratified random sampling was used in this study. In this research, questionnaires and interview guides for interviews were the research instruments used.

\section{Data Analysis}

Responses from school heads, teachers, parents and pupils were presented using simple tables and a column graph. The researcher presented all responses from closed and open ended questions together with interview responses. Tables and a graph were used to present data since they make data easier to interpret, to compare and contrast. Data presentation on tables was done in both real numbers and percentages. Percentages provide some description to responses and make drawing of column graphs easier. Column graphs were used mainly because they provide a pictorial presentation of data which makes it easy to note the relationship between presented data and cause and effect. This made it easy to make conclusions and generalisations from the data presented. Analysis of data depended much on comparing the number of respondents who agreed and those who disagreed with opinions to do with corporal punishment's effectiveness in dealing with deviant behaviour in pupils in schools and matching suggestions with the number of respondents who proposed for it.

\section{Data Presentation and Analysis}

4.1 Research question 1: Why do teachers and school heads use corporal punishment in dealing with deviant behaviour in pupils?

Table 1. Reasons for using corporal punishment and respondents' views. $(n=60)$

\begin{tabular}{lllll} 
Reasons for corporal punishment infliction & \multicolumn{2}{c}{ YES } & & NO \\
\hline & $\mathbf{n}$ & $\%$ & $\mathbf{n}$ & $\%$ \\
A. to control pupils' behaviour & 51 & 85 & 9 & 15 \\
B. to teach good morals & 31 & 51.7 & 29 & 48.3 \\
C. to set an example for others & 25 & 41.7 & 35 & 58.3 \\
D. it is the easiest way to punish & 10 & 16.7 & 50 & 83.3 \\
E. it deters further wrong doing & 33 & 55 & 27 & 45 \\
F. they want to be feared & 8 & 13.3 & 52 & 86.7 \\
G. they enjoy beating pupils & 7 & 11.7 & 53 & 88.3
\end{tabular}

From the research findings, 51 respondents (85\%) believed that teachers use corporal punishment in order to control the behaviour of pupils. Respondents who associated corporal punishment with deterrence of further wrongdoing were 33, constituting $55 \%$ of the respondents. Meanwhile, $51.7 \%$ of the respondents hailed corporal punishment for its ability to teach morals. However this is a very well-contested opinion among the respondents as shown by a very narrow margin between those for the opinion and those against it i.e. $51.7 \%$ versus $48.3 \%$ respectively.

The highest number of respondents; 53 out of $60(88.3 \%)$ are opposed to the opinion that teachers use corporal punishment because they enjoy beating pupils. Fifty-two respondents (86.7\%) do not buy the idea that when teachers corporally punish deviant pupils, they do it in order to be feared by pupils. In the same manner, $83.3 \%$ of the respondents disagree with the opinion that teachers and school heads find corporal punishment to be the easiest punishment for them to administer and for that reason, they are at easy to use it on deviant pupils.

\subsection{Research question 2: How effective is corporal punishment in controlling and eradicating deviant behaviour?}

Fig. 1 below shows the extent to which respondents view corporal punishment as effective or ineffective on deviant behaviour control and eradication $(n=60)$. 


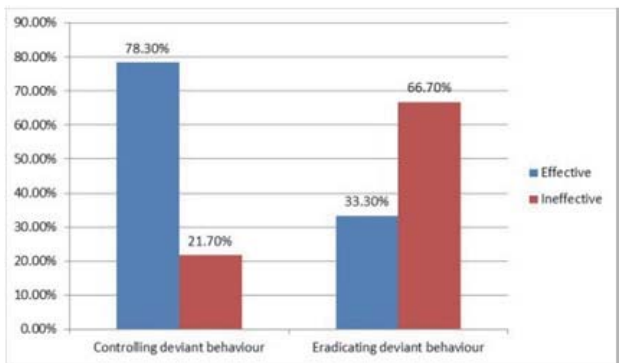

Fig. 1. Views on corporal punishment's ability to control and eradicate deviant behaviour in school pupils.

From Fig.1, it is very clear that the majority of respondents (41) which is $68.3 \%$ believed that corporal punishment is effective in controlling deviance. On the contrary,(10), $61.7 \%$ of the respondents felt that corporal punishment is ineffective when it comes to eradicating the deviant behaviour. Five (5\%) of the respondents (3) declared corporal punishment very ineffective in both controlling and eradicating deviant behaviour. In summary and as shown on the column graph, respondents overwhelmingly concurred with the opinion that corporal punishment can effectively control deviant behaviour as opposed to eradicating it. On controlling deviant behaviour, corporal punishment was endorsed by a total of (47), $78.3 \%$ of the respondents against an insignificant (13), and $21.7 \%$.

Responses against corporal punishment's ability to eradicate deviant behaviour in pupils surpassed those in its support by a crushing $33.4 \%$ as (39 respondents), $66.7 \%$ expressed that corporal punishment is ineffective in eradicating deviant behaviour against (20), 33.3\% who uphold it for the function.

4.3 Research question 3: Does corporal punishment enable behaviour reflection and reformation in pupils as well as retaining pupils in the school system?

Table 2. The extent to which respondents agreed or disagreed with the mentioned abilities of corporal punishment $(n=60)$.

\begin{tabular}{lcccccccr} 
Punishment's ability & & A & \multicolumn{2}{c}{ SA } & \multicolumn{2}{c}{ D } & \multicolumn{2}{c}{ SD } \\
\hline & $\mathbf{n}$ & $\%$ & $\mathbf{n}$ & $\%$ & $\mathbf{n}$ & $\%$ & $\mathbf{n}$ & $\%$ \\
A. behaviour reflection & 19 & 31.7 & 4 & 6.7 & 26 & 43.3 & 11 & 18.3 \\
B.retaining pupils & 12 & 20 & 7 & 11.6 & 38 & 63.3 & 3 & 5
\end{tabular}

Results on Table 2 show views of respondents on whether corporal punishment enables behaviour reflection in deviant pupils and pupils' retention or not. In summary 37 out of 60 respondents which is $61.7 \%$ disagreed with the claim that corporal punishment enables behaviour reflection. In the same vein, (41) that is $68.3 \%$ of the respondents disassociated corporal punishment from retaining pupils in the school system.

However, (23), 38.3\% of the respondents agreed to the idea that corporal punishment promotes behaviour reflection (self behaviour evaluation and introspection) and (19), 31.7\% agreed that corporal punishment can retain pupils in the school system, with (7), $11.6 \%$ strongly holding to that notion.

Table 3. Summary of responses as percentages of those who agree and those that disagree that corporal punishment reforms pupils' behaviour $(n=35)$.

\begin{tabular}{lcccc} 
Corporal punishment quality & \multicolumn{2}{c}{ YES } & \multicolumn{2}{c}{ NO } \\
\hline & $\mathbf{n}$ & $\%$ & $\mathbf{n}$ & $\%$ \\
A. behaviour reform & 16 & 45.7 & 19 & 54.3
\end{tabular}

Table 3 shows results to do with corporal punishment and its ability to reform behaviour of deviant pupils as perceived by the respondents. There is not much difference between those who credit corporal punishment for deviant behaviour reform and those who discredit it. It is a much contested opinion. Nineteen out of thirty-five respondents which is $54.3 \%$ of the respondents expressed that corporal punishment cannot reform pupils' deviant behaviour while (16), $45.7 \%$ agreed that corporal punishment can reform deviant pupils' behaviour.

\subsection{Research question 4: What improvements can be made to corporal punishment in schools to make it more effective?}

Below is a table showing the respondents' suggestions on how corporal punishment can be improved. 
Table 4. Suggestions on how corporal punishment can be improved $(n=35)$.

$\begin{array}{llr}\text { Respondents' suggestions } & \text { n } & \% \\ \text { A. to be done by parents at home } & 1 & 2.9 \\ \text { B. to be done by parents in the school } & 5 & 14.3 \\ \text { C. to be done by class teachers in the school head's office } & 7 & 20 \\ \text { D. to be done in the classroom by the head } & 12 & 34.2 \\ \text { E. to be done by the teacher in the classroom } & 7 & 20 \\ \text { F. to be applied to both, boys and girls } & 2 & 5.7 \\ \text { G. no improvements should be made } & 1 & 2.9\end{array}$

Various suggestions to improve corporal punishment have been given by respondents. Top among them are that the school head should carry out the corporal punishment in the classroom so as to set an example to the would be offenders in that class. This has been suggested by (12), $34.2 \%$ of the respondents and is the highest backed suggestion among others.

Other respondents especially teachers felt that corporal punishment should be carried out by them but under the school head supervision. There is also the suggestion by (5), 14.3\% of the respondents that parents should be allowed to corporally punish their children at school instead of leaving this to the school head's responsibility. The suggestion that the class teachers should be allowed to corporally punish the pupils in their classes under the school head's supervision and the other that it is the class teacher who should carry out the punishment under the school head's supervision and in the administrator's office have their support at par, $20 \%$ each. Some respondents are of the opinion that the current corporal punishment in schools is gender biased since it is only applicable to boys and girls are exempted from it. However, a single respondents, $2.9 \%$ expressed contentment with the status quo and wants corporal punishment maintained as it is.

\section{Discussion}

\subsection{Research question 1- Why do teachers and school heads use corporal punishment in dealing with deviant behaviour} in pupils?

The research findings reveal that more respondents perceived the use of corporal punishment by teachers and school heads as something purported at controlling of pupils' deviant behaviour than those who viewed it as being used for achieving personal and selfish interests. Responses on items $a, b$, and $c$ of the research question 1.pointed to the fact that corporal punishment is viewed as serving the purpose of behaviour control, teaching morals and deterrence of further wrongdoing.

The above findings are consistent with the findings by Chemhuru (2010), who asserts that punishment is not necessarily used as an end in itself, but it is used as a means to achieve some good end, that is good behaviour which is compatible with the process of education. The purpose for which it is used is to enable the smooth and successful education process through creating a disturbance free and a conducive environment that benefits learners.

Respondents overwhelmingly dismissed the opinion that teachers and school heads corporally punish pupils for selfish interests such as for them to be feared by the pupils, to derive joy from beating pupils and selecting corporal punishment as a strategy that is easy to implement rather than considering its impact on the unwanted behaviour. This tally with Shumba et al. (2001) findings which show that only $37 \%$ of the pupils questioned in a survey were of the opinion that teachers corporally punish pupils so that their power is felt by the pupils.

Corporal punishment by teachers and school heads is also regarded by (33), 55\% of the respondents as aimed at deterring further wrong doing. This is the same view with Baumrid et al (2002) and Balogun (2009:49) who says, "Punishment as a deterrence may either deter or the would be or potential criminals or offenders from carrying out the same wrong later in future." This is based on the understanding that the purpose of punishing the wrongdoers or criminals is to deter, prevent or frighten other people from doing the same wrong or criminal act (Dzurgba, 2006). An example is set through punishing the wrongdoers that deviant behaviour has dire consequences that may not persuade others into acting in the same manner, but demotivate them. This brings up the idea of using corporal punishment as an example, the notion to which (25), $41.7 \%$ of the respondents subscribe.

The majority of the respondents indicated that they favour using corporal punishment to control deviant behaviour and deter deviant pupils from further wrongdoing. When (51), 85\% of the respondents regard corporal punishment in controlling deviant behaviour then it also shows that teachers seem not to look closely at the causes of various deviant behaviours before punishing the pupils. This seems so because it is unimaginable to think that various deviant behaviours emanate from the same causes hence the same treatment and control for them in form of corporal 
punishment. This brings the suspicion that corporal punishment is used for various offenses just because teachers find it an ease way to punish rather than a way that matches the cause of the deviant behaviour.

\subsection{Research question 2-How effective is corporal punishment in controlling and eradicating deviant behaviour in pupils?}

Responses from this survey reveal that corporal punishment effectively controls deviant behaviour in pupils. Controlling means having direction over or restraining something. In this case deviant behaviour is restrained by corporal punishment. The findings are congruent with an assertion by Gawlick, Henning and Warner (2006) who post that the desired outcome of physical punishment is immediate child compliance with adult directives.

When teachers and school heads use corporal punishment, pupils comply with their directives in order to avoid the pain that is inseparable with corporal punishment. Pupils are therefore deterred from acting in a deviant manner even if this is forced compliance. This tallies with what Smith et al (2004) who assert that the desired outcome of physical punishment is child compliance with adult directives. It is observed that when school heads and teachers observe the disappearance of deviance from the previously deviant pupils, they are confident and quick to believe that corporal punishment has accomplished the work, hence overwhelmingly upholding it for controlling deviance.

On the contrary, the majority of respondents have passed a vote of no confidence on corporal punishment's ability to eradicate deviant behaviour despite acknowledging its strength on controlling the same behaviour. It sounds paradoxical that corporal punishment fails to eradicate the behaviour that it can "control". But when closely examined, this is very consistent with the normal expectations. Control does not always and automatically culminate in eradication. Eradication is much more complex than just deterrence which is synonymous with control.

Moreover, eradication of deviance also includes self restrain from misbehaviour than an imposed restrain which is usually a result of corporal punishment. Extrinsic restrain of deviant behaviour is far from equipping children with expected societal attitudes and values that enable moral internalisation (Kerr et al. 2004). To eradicate deviance, the morals internalised by the children then substitute the deviant behaviour. However these values are unavailable in punishment but found in induction (Holden, 2002).

Deviant behaviour restrain without eradication is usually the norm in the schools. This is the very reason why some deviant behaviour controlled through corporal punishment recur and the teachers and school heads conclude that these pupils no longer succumb to the pain brought by corporal punishment. This is consistent with Kochanska (2001) who asserts that only committed and not forced compliance is the first step towards internal control which eventually leads to behaviour reform.

From some interviewed teachers, it became clear that they have to keep a whip in the classroom in order to keep the once punished for misbehaviour out of their classes. The moment they discontinue corporal punishment, deviance surfaces. Some deviant pupils take the chance to misbehave when the teacher or the head is out of sight which shows that thriving by corporal punishment in a class for behaviour control is rule by fear and not reason. Rationalisation is the soul of moral internalisation which result in eradication of deviant behaviour. Therefore, for eradication of deviant behaviour in pupils, control alone through corporal punishment does not suffice.

\subsection{Research question 3-Does corporal punishment enables behaviour reflection and reformation in pupils as well as retaining pupils in the school system?}

The findings on research question three reveal that the majority of respondents are of the opinion that corporal punishment can neither promote behaviour reflection nor retain pupils in the school system. Most of the pupils in this study indicated that they either feel humiliated or angry as a result of corporal punishment infliction on them. These feelings seem antagonistic to the feeling of remorse that can lead to behaviour reflection. Humiliation and anger shuts the opportunity and wipes away the urge for one to engage in self introspection on their behaviour. Rather than promoting behaviour reflection, corporal punishment may promote retaliation in an effort to counter humiliation and satisfy anger.

As of retaining pupils in the school system, few respondents (19), which is $31,7 \%$ attributed corporal punishment to solving the truancy problem. For this, it is claimed that when truant pupils are corporally punished, they are compelled to regularly attend school. However, the majority of respondents argued that the root cause of truancy remain undiscovered and unsolved, and keeps motivating the pupils to be truant whenever corporal punishment ceases to be applied on them.

In addition (41),68,3\% of the respondents expressed that corporal punishment cannot retain pupils in the school, thereby holding it accountable to causing school dropouts. That which does not retains does disperse. By implication, if corporal punishment fails on retaining pupils it may then pass in promoting school dropouts. This research's findings that corporal punishment does not promote pupils retention tallies with the United Nations (2008) Survey in Pakistan which 
revealed that large numbers of pupils, as many as 35000 drop out of school annually due to corporal punishment. The same survey also attributed $50 \%$ of the world's school dropouts to corporal punishment.

The ability of corporal punishment to reform deviant behaviour in pupils has been dismissed by (19), $54.3 \%$ of the respondents while (16), $45.7 \%$ hailed it. Such a contestation is likely to be a result of the fact that corporal punishment has been found to be successful in controlling (restraining) deviant behaviour and also deter further wrongdoing. Control and deterrence of deviant behaviour makes it invisible which by error can be easily concluded that behaviour reform has taken place.

Behaviour reform is more than deterrence and control. It also involves moral internalisation (Kerr et al. 2004). There is need for verbal disciplinary methods that include explanation and reasoning in order to provide the deviant pupils with cognitive stimulus to reflect on their behaviour as well as internalising societal values and attitudes (Straus, 2001). If corporal punishment cannot eradicate deviant behaviour as shown by responses on question 2, then there is no way it can be associated with deviant behaviour reform. As indicated by the majority of respondents, corporal punishment doesn't teach morals.

\subsection{Research question 4-What improvements can be made to corporal punishment in schools to make it more effective?}

The feeling among some teachers is that pupils who are corporally punished by the school head for the offenses they commit in the classroom do not appreciate the teacher's responsibility in controlling their behaviour but only the school head's (Ajaja, 2012). They say that this may cause disciplinary problems for the teacher in the classroom. When the school head is absent at school and the pupils know it then they are tempted to misbehave on that day. Teachers feel that the in-loco parentis responsibility of the class teachers should extend to them being also allowed to corporally punish pupils (Azzam, 2007; Magagula, 1992). However, they agree to doing this in the presence of the school head.

Teachers differed on where the punishment should be carried out. Others felt that they should carry it out in the classroom to set an example for others. This is the deterrence approach to punishment (Owoade, 1998). Others believed that even if it is carried out in the head's office as long as it is carried out by the teacher then it will be effective.

It has also been discovered in this research that in some secondary schools, it is now a norm that parents are called to beat their misbehaving children at school though this is not spelt out in the circulars that direct the administration of corporal punishment to pupils in schools. The school authorities claim that this practice helps in showing the deviant pupils that the school teachers and their parents are in solidarity in condemning their deviant behaviour.

However, from the interviews with some teachers resulted in the revelation that the school authorities do this to avoid confrontation or threats of unspecified consequences from some parents who oppose the idea of corporal punishment in schools and from the deviant and corporally punished pupils. This appears to be consistent with research that claims that physically abused children tend to become more rebellious (Poole et al. 2003). These parents, it has also been revealed, that they are forced to beat their children since they are given two options, either to beat their children or to have them expelled from school. Though the parents may be coerced, it also reveals that some parents are totally ignorant of the regulations that govern their children's discipline in schools and to them, whatever teachers do is right (Dubanoski, Inaba \& Gerkewicz, 1993).

There are also some respondents who suggested that there lacks justice or fairness on the current way of corporally punishing pupils as it segregates pupils by sex. Same treatment should be given for the same offense to achieve or fairness. They feel that if the punishment is human enough, then it should also be allowed on girls. The selective nature of corporal punishment is said to promote rebellion and gender inequality while reaffirming the gender stereotype that women are weaker than men physically and in many other respects and that girls cannot withstand what boys can.

\section{Conclusion}

In conclusion, teachers and school heads use corporal punishment chiefly as a behaviour control mechanism, deterrence for further wrong doing and for setting an example for would be offenders. Even the pupils to whom corporal punishment is inflicted are convinced and appreciate corporal punishment's role in controlling their behaviour. They perceive it as instrumental in creating a disturbance free learning environment, the same way as their teachers. Corporal punishment has been found to be effective in temporarily controlling deviant behaviour in pupils. Restraining deviant behaviour also culminate in control of that behaviour. However restraining deviant behaviour is not a guarantee that the behaviour will automatically be eradicated and this control is short-lived. Therefore, corporal punishment on its own has been found to be ineffective in deviance eradication. For deviance eradication to occur, there should be moral internalisation by the 
deviant pupils and this is achieved through positive discipline and not punishment alone. Corporal punishment should only be used to reinforce the already internalised morals.

\section{Recommendations}

On the basis of the findings of this study, the following efforts are recommended to help school heads and teachers deal with deviant behaviour in schools without using abusive corporal punishment.

Schools should practise widening and diversifying their disciplinary strategies and not solely rely on corporal punishment. Positive discipline and induction such as explanations, rationalisation, discussions with deviant pupils and rewards for good behaviour rather than punitive measures may work better to transform pupils' behaviour.

Though laws are essential in regularising and directing operations, they can be complemented by educational programs that examine a broad range of issues related to corporal punishment in teacher education courses. This way the rift between the physical punishment recommended by the Zimbabwe education laws, the actual definition of corporal punishment and what happens in the schools can be bridged.

When teachers and school heads carry out redirection, discipline or punishment they must include an explanation of why a behaviour is unacceptable and what behaviour is acceptable. This is because many a times a child's misbehaviour is a mistake in judgement. As adults we hope our mistakes serve as learning opportunities and the same rule should apply to children. We should therefore curb our anger and allow time to think about what morals we want to teach rather than relying on punishments.

\section{References}

Ajaja, P.O. (2012). School Dropout Pattern among Senior Secondary Schools in Delta State, Nigeria. International Education Studies, 5 (2): 23-28. Azzam, A.M. (2007). Why students drop out. Educational Leadership, 64 (7): 91-93.

Balogun, O.A (2009). A Philosophical Defence of Punishment in Traditional AfricanLegal Culture: The Yoruba Example. Journal of Pan African Studies, 3 (3) : 43-54.

Baumrid, D., Larzelere R.E and Cowan, P.A. (2002). Ordinary physical punishment: Is it Harmful? Comment of Gershoff. Psychological Bulletin, 128(4): 580-589.

Best, L.W and Khan, J.V. (2003). Research in Education (7th edition).Eaglehood Cliffs: Prentice Hall.

Cashmore, J, and de Haas, N. (1995). Legal and social aspects of the physical punishment of children. Canberra: Department of Human Services and Health Press.

Chemhuru, M. ( 2010). Revisiting the place of corporal punishment in Zimbabwe's primary and secondary school formal education system. Journal of African Studies and Development, 2(7):176-183

Chiromo, A. (2006). Research Methods and Statistics in Education. Harare: Beta Print.

Cohen, L and Manion, L. (1994). Research Methods in Education. London: Routledge and Kegan.

Constitution of Zimbabwe 1979.Article 15, Statutory Instrument 65 of 1992. Harare: Government Printers

Dubanoski, R.A., Inaba, M and Gerkewicz, K. (1993). Corporal Punishment in Schools: Myths, Problems and Alternatives. Child Abuse \& Neglect, 7: 271-278.

Dzurgba, A. (2006). Principles of Ethic. Ibadan: Agape Publications.

Ezewu, E. (1996). Introduction to Sociology of Education. Singapore: Longman Publishers Press Limited.

Kochanska, G. (2001). The development of self-regulation in the first four years of life. Child Development, 72(4): 1091-1111.

Magagula, C. (1992). To Flog or Not to Flog: A Literature Review. BOLESWA Educational Research Journal, 9:1-17.

Owoade, M.A. (1998). Capital Punishment: Philosophical Issues and Contemporary Problems in Nigeria, in Second Order (New Series): Afr. J. Philos., 1:23-29

Poole, S.R., Ushokow, M.C and Nader, P.R. (2003). Corporal Punishment in Schools: Position Paper of the Society for Adolescent Medicine.Journal of Adolescent Health, 32, 385-393.

Shumba, A., Mpofu, E., Chireshe, R and Mapfumo, J. (2001).The Epidemiology and Aetiology of Child Abuse by Teachers in Zimbabwean Primary Schools. Child Abuse and Neglect: The International Journal, 25, 265-277.

Shumba, A. (2003). Pupil Physical Abuse by Secondary School Teachers in Zimbabwe: A Child-Rearing Practice or Cultural Dilemma? Journal of Aggression, Maltreatment \& Trauma, 8(4) :143-159.

Smith, A.B., Gollop, M.M., Taylor, N.J and Marshall, K.A.( 2004) .The discipline and Guidance of children: A summary of research. Dunedin, NZ: Children's Issues Centre.

Straus, M.A. (2001). New evidence for the benefits of never smacking.Society, 83(6): 52-60

Straus, M.A and Stewart, J.H. (1999). Corporal punishment by American parents: National data on prevalence, chronicity, severity and duration, in relation to child and family characteristics. Clinical Child and Family Psychology Review, 2(2):5-70.

Zindi, F. (1995). An Analysis of the arguments for and against Corporal Punishment in Zimbabwe. Zimbabwe Journal of Education Research, 7(1), 69-83. 